\title{
Red American Ginseng and Breast Cancer
}

\author{
Chong-Zhi Wang, Guang-Jian Du and Chun-Su Yuan \\ Tang Center for Herbal Medicine Research and Department of Anesthesia \& Critical Care, \\ The Pritzker School of Medicine, University of Chicago, Chicago, \\ U.S.A.
}

\section{Introduction}

Breast cancer is the most frequently diagnosed form of cancer among women. Breast cancer is the leading cause of cancer death in nearly all developed countries, showing an increased incidence over the last decades, and the expected number of new U.S. patients in 2010 would be 209,060, and the death number will be 40,230 1. The clinical management of breast cancer invariably involves diverse conventional modalities, including surgery, chemotherapy, and radiation ${ }^{2}$. The complex characteristics of breast cancer may also require some alternative management to improve the therapeutic efficacy of conventional treatment and the quality of life for cancer patients ${ }^{3}$.

American ginseng (Panax quinquefolius L.) is a commonly used herb in the United States which belongs to the genus Panax L. in family Araliaceae ${ }^{4}$. Panax is a small genus, and nearly all species in this genus are important herbal medicines, especially Asian ginseng (Panax ginseng C. A. Meyer) ${ }^{5}$. Since Asian ginseng has been used as herbal medicine for a long history in oriental countries, many studies have been conducted on its constituents and its pharmacological effects ${ }^{6}$. Asian ginseng has many reported health benefits including anticancer activities ${ }^{7-9}$. In the 1990s, a case-control study on over a thousand Korean subjects showed that long-term ginseng consumption was associated with a decreased risk for many different cancers compared with those who did not consume ginseng 10,11. In contrast to many studies on Asian ginseng's anticancer effects, investigation of American ginseng is limited 7, and its mechanisms of action are largely unknown.

American ginseng extracts were found to inhibit the growth of breast cancer cells ${ }^{12}$. We previously investigated the effects of several herbal extracts on reducing chemotherapeutic side effects and found that American ginseng can attenuate cisplatin-induced nausea and vomiting in a rat model, while not affecting its anticancer properties in human cancer cells ${ }^{13}$. In addition, the extract from American ginseng enhanced the antiproliferation effect of cisplatin on human breast cancer cells, suggesting that it possesses its own anticancer activity ${ }^{13}$.

In Asia, ginseng root is air-dried into white ginseng or steamed at $100{ }^{\circ} \mathrm{C}$ to give red ginseng. It is believed that red ginseng is more pharmacologically effective than white ginseng ${ }^{14}$. The differences in the biological effects of white and red Asian ginseng are attributed to the significant changes in ginsenosides from the steaming treatment ${ }^{15}$. In this study, we treated American ginseng root at various temperatures and heating times. After heat-processing, the root of American ginseng, like Asian ginseng, changes from white to red; steamed P. quinquefolius root is therefore referred to as red American ginseng. 
Currently, the most popular herbal products are in extract forms. New regulations released by FDA on alternative complementary supplements require the botanical extracts to be standardized ${ }^{16}$. The contents of ginsenosides in the extracts were not assayed before. We treated American ginseng root at various temperatures and heating times. The contents of representative ginsenosides in unsteamed and steamed American ginseng root extracts were determined using HPLC. In addition to the cell line MCF-7, we also used the MDA-MB-230 human breast cancer cells to evaluate the chemopreventive activities of unsteamed and steamed American ginseng root extracts and four ginsenosides. To observe the anticancer mechanisms, the effects of American ginseng extracts and single compounds on apoptosis and cell cycle were evaluated.

\section{Materials and methods}

\subsection{Chemicals}

All solvents were of high-performance liquid chromatography (HPLC) grade from Fisher Scientific (Norcross, GA). Milli Q water was supplied by a water purification system (US Filter, Palm Desert, CA). Standards for ginsenosides $\mathrm{Rb}_{1}, \mathrm{Rb}_{2}, \mathrm{Rc}, \mathrm{Rd}, \mathrm{Re}$, and $\mathrm{Rg}_{1}$ were obtained from Indofine Chemical Company (Somerville, NJ); ginsenosides Rb3, Rg2, Rg3, Rh1, Rh2 and 20(R)-ginsenoside Rg2 (20R-Rg2) were obtained from the Delta Information Center for Natural Organic Compounds (Xuancheng, Anhui, China). All standards were of biochemical-reagent grade and at least $95 \%$ pure as confirmed by HPLC. All the plastic materials were purchased from Falcon Labware (Franklin Lakes, NJ). Trypsin, RPMI 1640 medium, fetal bovine serum (FBS), and penicillin/streptomycin solution (200x) were obtained from Mediatech, Inc. (Herndon, VA). A CellTiter 96 Aqueous One Solution Cell Proliferation Assay kit was obtained from Promega (Madison, WI). Annexin V-FITC, cyclin A-FITC and cyclin D1-FITC were obtained from BD Biosciences (San Diego, CA).

\subsection{Plant materials, processing and extraction}

American ginseng roots (Panax quinquefolius L.) were obtained from Roland Ginseng, LLC (Wausau, WI). The voucher samples were deposited at the Tang Center for Herbal Medicine Research at University of Chicago (Chicago, IL). For the heat-processing of American ginseng, the roots were steamed at $100^{\circ} \mathrm{C}$ and $120^{\circ} \mathrm{C}$ for $1 \mathrm{~h}$ or at $120^{\circ} \mathrm{C}$ for $0.5,1,2,3$, and $4 \mathrm{~h}$.

For the HPLC analysis, dried American ginseng sample ( $0.5 \mathrm{~g})$ was extracted with methanol in a Soxhlet extractor for $8 \mathrm{~h}$. The extract was concentrated, transferred into a $25-\mathrm{ml}$ volumetric flask and diluted to the desired volume with methanol. One millimeter of the solution was purified by solid-phase extraction ${ }^{17}$. Purified solutions were stored at $4{ }^{\circ} \mathrm{C}$ until HPLC analysis.

For the in vitro anti-cancer studies, the process for the extraction of American ginseng samples was as follows: A root sample, unsteamed or steamed at various temperatures and times, was ground to powder and passed through a 40 mesh screen. Then $25 \mathrm{~g}$ of powder was extracted with $500 \mathrm{ml}$ of $70 \%$ ethanol for $4 \mathrm{~h}$; the water bath was maintained at $90{ }^{\circ} \mathrm{C}$. When cooled, the solution was filtered with P8 filter paper (Fisher Scientific, Pittsburgh, PA) and the filtrate was collected. The residue was extracted with $500 \mathrm{ml}$ of $70 \%$ ethanol once more and then filtered while the solution was cooled. The filtrates were combined and the solvent was evaporated under vacuum. The dried extract was dissolved in $100 \mathrm{ml}$ water and then extracted with water-saturated $n$-butanol. The $n$-butanol phase was evaporated under vacuum and then lyophilized.

The root of P. quinquefolius L. was collected from Roland Ginseng, LLC (Wausau, WI, USA). 


\subsection{HPLC analysis}

The HPLC system was a Waters 2960 instrument (Milford, MA) with a quaternary pump, an automatic injector, a photodiode array detector (Model 996), and Waters Millennium 32 software for peak identification and integration. The separation was carried out on a $250 \times 3.2$ mm i.d., $5 \mu$, Ultrasphere C18 column (Alltech, Deerfield, IL) with a $7.5 \times 3.2 \mathrm{~mm}$ i.d. guard column. For HPLC analysis, a $20-\mu \mathrm{L}$ sample was injected into the column and eluted at room temperature with a constant flow rate of $1.0 \mathrm{ml} / \mathrm{min}$. For the mobile phase, acetonitrile (solvent A) and water (solvent B) were used. Gradient elution started with $18 \%$ solvent A and $82 \%$ solvent $\mathrm{B}$. Elution was changed to $21 \% \mathrm{~A}$ for $20 \mathrm{~min}$, then to $26 \% \mathrm{~A}$ for $3 \mathrm{~min}$ and held for $19 \mathrm{~min}$. It was then changed to $36 \%$ A for $13 \mathrm{~min}$, to $50 \%$ A for $9 \mathrm{~min}$, to $95 \%$ A for 2 $\mathrm{min}$, and held for $3 \mathrm{~min}$. Lastly elution was changed to $18 \%$ A for $3 \mathrm{~min}$ and held for $8 \mathrm{~min}$. The detection wavelength was set to $202 \mathrm{~nm}$. All tested solutions were filtered through Millex 0.2- $\mu \mathrm{m}$ nylon membrane syringe filters (Millipore Co., Bedford, MA) before use. The linearity of this method was assayed by analyzing standard solutions in the range of 2-400 $\mu \mathrm{g} / \mathrm{ml}$ for the 12 ginsenosides. Calibration curves were constructed from the measured peak areas and the related amount of ginsenosides. Ginsenosides Rb1, Rb2, Rb3, Rc, Rd, Re, Rg1, Rg2, 20R-Rg2, Rg3, Rh1 and Rh2 (Figure 1) in extract samples were identified by comparison of their retention times with those obtained from the chromatograms of mixed ginsenoside standards. The contents of saponins in each sample were calculated using standard curves of ginsenosides.

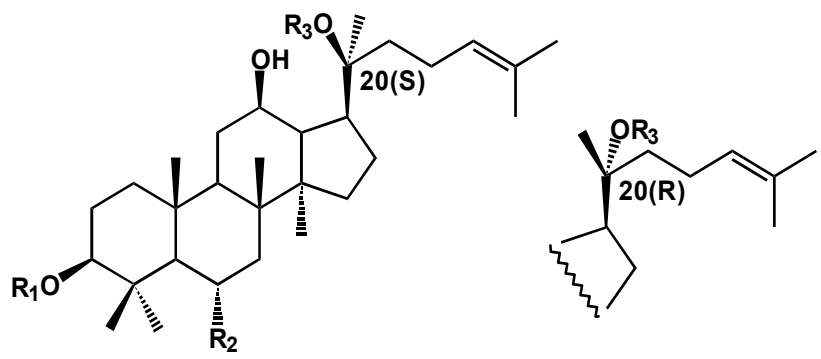

\begin{tabular}{|c|c|c|c|}
\hline Name & R1 & R2 & R3 \\
\hline Ginsenoside Rb1 & - glc $^{2}-1 \mathrm{glc}$ & $-\mathrm{H}$ & $20(S),-$ glc $^{6}-1$ glc \\
\hline Ginsenoside Rb2 & $-\mathrm{glc}^{2}-1 \mathrm{glc}$ & $-\mathrm{H}$ & $20(S),-$ glc $^{6}-1$ ara(pyr) \\
\hline Ginsenoside Rb3 & - glc $^{2}-1$ glc & $-\mathrm{H}$ & 20(S), - glc ${ }^{6}-{ }^{1} x y l$ \\
\hline Ginsenoside Rc & - glc $^{2}-1 \mathrm{glc}$ & $-\mathrm{H}$ & 20(S), - glc ${ }^{6-1}$ ara(fur) \\
\hline Ginsenoside Rd & - glc $^{2}-1 \mathrm{glc}$ & $-\mathrm{H}$ & $20(S),-$ glc \\
\hline Ginsenoside Re & $-\mathrm{H}$ & -O-glc ${ }^{2}{ }^{1}$ rha & $20(S),-$ glc \\
\hline Ginsenoside Rg1 & $-\mathrm{H}$ & -O-glc & 20(S), -glc \\
\hline Ginsenoside Rg2 & $-\mathrm{H}$ & $-\mathrm{O}-\mathrm{glc}^{2}{ }^{1}{ }^{1} \mathrm{rha}$ & $20(S),-H$ \\
\hline 20R-ginsenoside Rg2 & $-\mathrm{H}$ & -O-glc ${ }^{2}{ }^{1}$ rha & $20(\mathrm{R}),-\mathrm{H}$ \\
\hline Ginsenoside Rg3 & - glc $^{2}-1$ glc & $-\mathrm{H}$ & $20(\mathrm{~S}),-\mathrm{H}$ \\
\hline Ginsenoside Rh1 & $-\mathrm{H}$ & -O-glc & $20(S),-H$ \\
\hline Ginsenoside Rh2 & -glc & $-\mathrm{H}$ & $20(S),-H$ \\
\hline
\end{tabular}

Fig. 1. Chemical structures of assayed ginsenosides in American ginseng. 
Ginsenoside $\operatorname{Rg} 3$ increased significantly from 0.5 to $3 \mathrm{~h}$ of steaming. Ginsenoside Rh2 is also an active anticancer saponin, however, after steaming treatment, the content of Rh2 was very low (Table $\mathbf{1})$.

\begin{tabular}{|c|c|c|c|c|c|c|c|c|}
\hline \multirow{2}{*}{ Ginsenoside } & \multirow{2}{*}{$\begin{array}{c}\text { Asian } \\
\text { Ginseng }\end{array}$} & \multirow{2}{*}{$\begin{array}{c}\text { Red Asian } \\
\text { Ginseng }\end{array}$} & \multirow{2}{*}{$\begin{array}{c}\text { American } \\
\text { Ginseng }\end{array}$} & \multicolumn{5}{|c|}{ Steaming Time (Red American Ginseng) } \\
\hline & & & & $0.5 \mathrm{~h}$ & $1 \mathrm{~h}$ & $2 \mathrm{~h}$ & $3 \mathrm{~h}$ & $4 \mathrm{~h}$ \\
\hline $\operatorname{Rg} 1$ & 0.279 & 0.276 & 0.133 & 0.098 & 0.075 & 0.017 & ND & ND \\
\hline $\operatorname{Re}$ & 0.234 & 0.188 & 1.750 & 1.347 & 0.968 & 0.221 & 0.032 & ND \\
\hline Rh1 & ND & 0.015 & ND & 0.008 & 0.017 & 0.040 & 0.042 & 0.049 \\
\hline $\operatorname{Rg} 2$ & 0.031 & 0.034 & 0.015 & 0.154 & 0.266 & 0.405 & 0.444 & 0.363 \\
\hline $20 R-\operatorname{Rg} 2$ & ND & 0.022 & ND & 0.086 & 0.155 & 0.388 & 0.425 & 0.422 \\
\hline $\mathrm{Rb} 1$ & 0.545 & 0.462 & 4.940 & 3.918 & 3.252 & 1.743 & 0.735 & 0.177 \\
\hline Rc & 0.523 & 0.294 & 0.387 & 0.325 & 0.278 & 0.141 & 0.087 & 0.018 \\
\hline $\mathrm{Rb} 2$ & 0.443 & 0.200 & 0.043 & 0.042 & 0.036 & 0.026 & 0.018 & ND \\
\hline $\mathrm{Rb} 3$ & 0.067 & 0.032 & 0.063 & 0.064 & 0.050 & 0.035 & 0.017 & ND \\
\hline $\mathrm{Rd}$ & 0.257 & 0.073 & 0.604 & 0.510 & 0.460 & 0.335 & 0.206 & 0.097 \\
\hline Rg3 & 0.004 & 0.033 & 0.003 & 0.143 & 0.271 & 0.664 & 1.053 & 1.225 \\
\hline Rh2 & ND & 0.009 & 0.007 & 0.007 & 0.018 & 0.047 & 0.057 & 0.066 \\
\hline Total & 2.38 & 1.64 & 7.95 & 6.70 & 5.85 & 4.05 & 3.11 & 2.42 \\
\hline
\end{tabular}

$\mathrm{n}=3$; ND, not detected; values are expressed as percentage of dry weight; RSD (relative standard derivation) are less than $15 \%$.

Table 1. Ginsenoside contents in Asian ginseng, red Asian ginseng and American ginseng which were unsteamed or steamed at $120^{\circ} \mathrm{C}$ for $0.5-4 \mathrm{~h}$.

\subsection{Cell culture}

The human breast cancer cell lines MCF-7 and MDA-MB-231 were purchased from American Type Culture Collection, ATCC (Manassas, VA, USA) and grown in RPMI 1640 medium supplemented with $10 \%$ FBS and 50 IU penicillin/streptomycin in a humidified atmosphere of $5 \% \mathrm{CO}_{2}$ at $37^{\circ} \mathrm{C}$.

\subsection{Cell proliferation analysis}

Cells were seeded in 96-well plates. After $1 \mathrm{~d}$, various concentrations of extracts/ginsenosides were added to the wells. The final concentration of ethanol was $0.5 \%$. Controls were exposed to culture medium containing $0.5 \%$ ethanol without drugs. All experiments were performed in triplicate and repeated 3 times. Cell proliferation was evaluated using an MTS assay according to the manufacturer's instructions. Briefly, at the end of the drug exposure period, the medium was replaced with $100 \mu \mathrm{l}$ of fresh medium, 20 $\mu \mathrm{l}$ of MTS reagent (CellTiter 96 Aqueous Solution) in each well, and the plate was returned to the incubator for 1-2 h. A $60-\mu \mathrm{l}$ aliquot of medium from each well was transferred to an ELISA 96-well plate and its absorbance at $490 \mathrm{~nm}$ was recorded 4,18 . Results were expressed as percentage of control (ethanol vehicles set at $100 \%$ ). 


\subsection{Apoptosis assay}

Cells were seeded in 24-well tissue culture plates. After culturing for 1 day, the medium was changed and extracts/ginsenosides were added. After treated for $48 \mathrm{~h}$, cells floating in the medium were collected. The adherent cells were detached with $0.05 \%$ trypsin. Then culture medium containing 10\% FBS (and floating cells) was added to inactivate trypsin. After being pipetted gently, the cells were centrifuged for $5 \mathrm{~min}$ at $1500 \mathrm{~g}$. The supernatant was removed and cells were stained with annexin V-FITC and propidium iodide according to the manufacturer's instructions. Untreated cells were used as control for double staining. Cells were analyzed immediately after staining using a FACScan flow cytometer (Becton Dickinson, Mountain View, CA) and FlowJo 7.1.0 software (Tree Star, Ashland, OR). For each measurement, at least 20,000 cells were counted.

\subsection{Cyclin A and cyclin D1 assay}

Cells were seeded in 24-well tissue culture plates. On the second day, the medium was changed and cells were treated with extracts. Cells were incubated for $48 \mathrm{~h}$ before the cells were harvested. The cells were fixed gently by putting $80 \%$ ethanol in freezer for $2 \mathrm{~h}$ and were then treated with $0.25 \%$ Triton X-100 for $5 \mathrm{~min}$ on ice bath. Cells were resuspended in $300 \mathrm{ul}$ of PBS containing $40 \mu \mathrm{g} / \mathrm{ml}$ propidium iodide and $0.1 \mathrm{mg} / \mathrm{ml}$ RNase. Then, $20 \mu \mathrm{l}$ of cyclin A-FITC or cyclin D1-FITC was added to the cell suspension. Then the cells were incubated in a dark room for $20 \mathrm{~min}$ at room temperature, and analyzed with a FACScan flow cytometer. For each measurement, at least 20,000 cells were counted.

\subsection{Cell cycle assay}

After cells were treated with extracts/ginsenosides, the cells were harvested in similar manner to the method used in the cyclins assay. Then, the cells were stained with propidium iodide, and analyzed with a FACScan flow cytometer. For each measurement, at least 20,000 cells were counted.

\subsection{Statistical analysis}

Data are presented as mean \pm standard deviation (SD) with $n=3$. A one-way ANOVA determined whether the results had statistical significance. In some cases, Student's t-test was used for comparing two groups. The level of statistical significance was set at $\mathrm{P}<0.05$.

\section{Results}

\subsection{Saponin composition changes in extracts during heat-processing}

Twelve ginsenosides (Figure 1) were determined in American ginseng using high performance liquid chromatography (HPLC). All the assayed ginsenosides were dammarane glycosides 17,19 . The influence of steaming at $100^{\circ} \mathrm{C}$ and $120^{\circ} \mathrm{C}$ on the ginsenoside content of American ginseng was tested. Compared with unsteamed American ginseng, the roots treated at $100^{\circ} \mathrm{C}$ for $1 \mathrm{~h}$ decreased total ginsenoside content slightly, from $7.95 \%$ to $7.32 \%$. For the main saponin contents, ginsenoside Rb1 was changed from $4.940 \%$ to $4.463 \%$, and Re was from $1.756 \%$ to $1.630 \%$; ginsenoside $\operatorname{Rg} 3$ increased from $0.003 \%$ to $0.048 \%$. Steaming at $120^{\circ} \mathrm{C}$ for $1 \mathrm{~h}$ decreased the total ginsenoside content to $5.85 \%$, as follows: Rb1, 3.252\%; Re, $0.968 \%$; and Rg3, 0.271\%. Ginsenoside Rg3 increased significantly at $120^{\circ} \mathrm{C}$. 
Chromatograms of unsteamed and steamed American ginseng roots for 2 and $4 \mathrm{~h}$ at $120^{\circ} \mathrm{C}$ are shown in Figure 2. The peak areas of $\mathrm{Rb} 1, \mathrm{Rd}$ and Re decreased during the steaming process. On the other hand, ginsenoside Rg3, which is a trace saponin in unsteamed root 17 , was augmented during the steaming process (Figure 3). The content of the 12 ginsenosides in steamed American ginseng roots is shown in Table 1. During the steaming process, $\operatorname{Rg} 1$, Re, Rb1, Rc, Rb2, Rb3, and Rd decreased; Rh1, Rg2, 20R-Rg2, Rg3 and Rh2 increased.

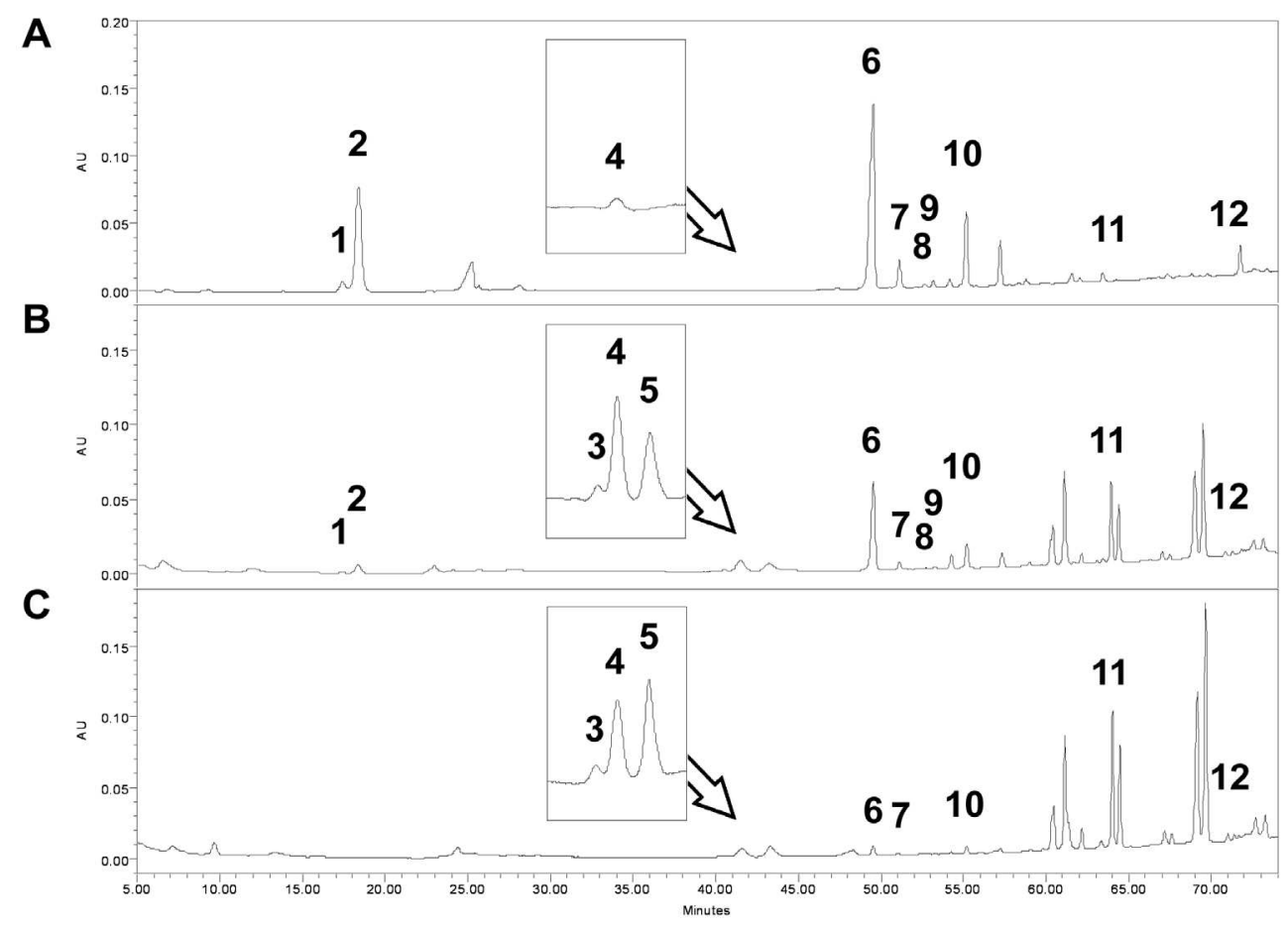

Fig. 2. HPLC analysis of ginsenosides in unsteamed and steamed American ginseng roots. Chromatograms of unsteamed (A), or steamed at $120^{\circ} \mathrm{C}$ for $2 \mathrm{~h}(\mathbf{B})$ and $4 \mathrm{~h}(\mathbf{C})$ are shown. Ginsenoside peaks: (1) Rg1, (2) Re, (3) Rh1, (4) Rg2, (5) 20R-Rg2, (6) Rb1, (7) Rc, (8) Rb2, (9) Rb3, (10) Rd, (11) Rg3, (12) Rh2. Peak numbers are not shown if saponins were not detected.

The chemical constituents of white ginseng and red ginseng ( $P$. ginseng C. A. Meyer) were also determined. Data shown in Table 1 indicated that for the Asian ginseng, after steaming at $100^{\circ} \mathrm{C}$, the contents of the main ginsenosides (Rg1, Re, Rb1, Rb2, Rc and $\mathrm{Rd}$ ) were decreased. Ginsenoside Rg3 increased from $0.004 \%$ to $0.033 \%$. The changes of ginsenoside contents are similar to that of American ginseng steamed at $100^{\circ} \mathrm{C}$. 


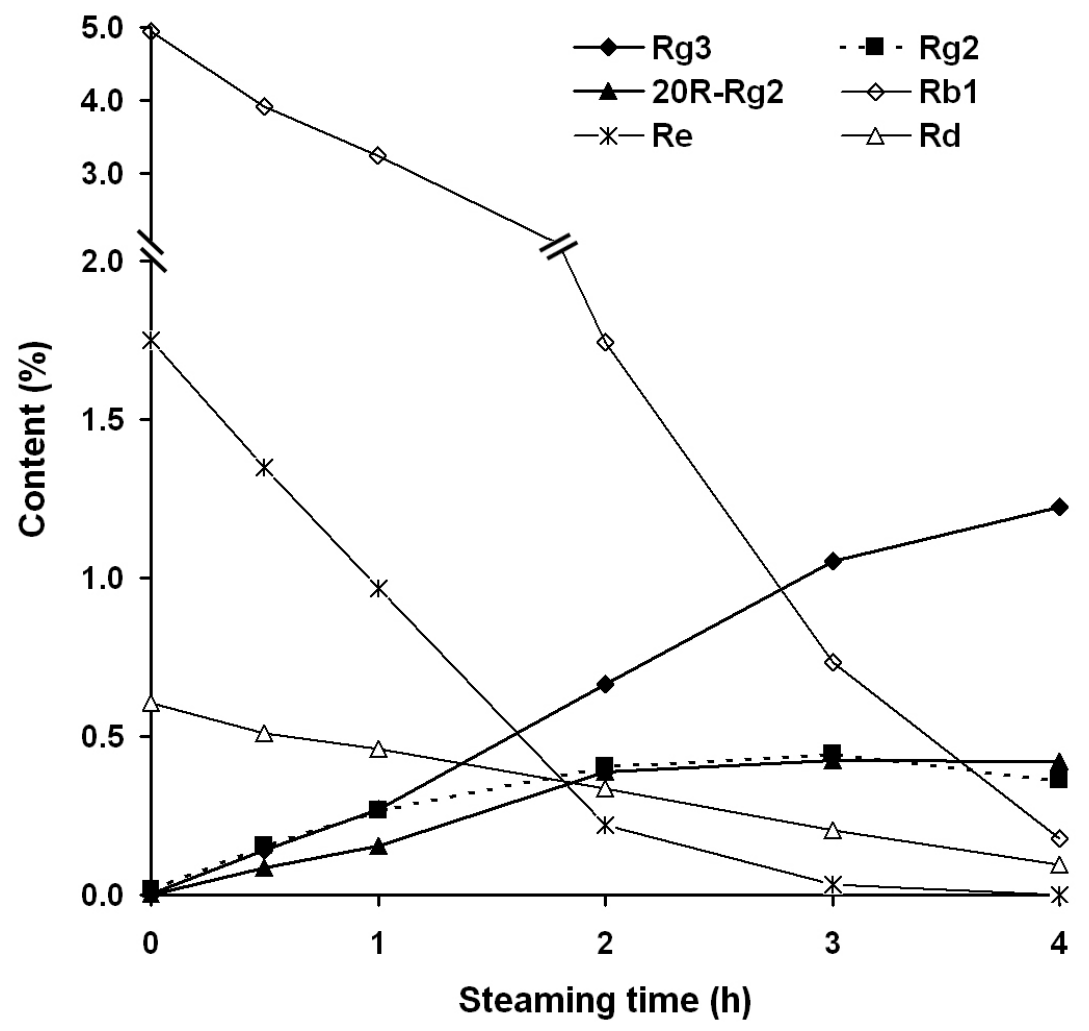

Fig. 3. Saponin content in American ginseng roots steamed at $120^{\circ} \mathrm{C}$ for $0-4 \mathrm{~h}$. The content of six major ginsenosides was changed during the steaming process.

\subsection{Antiproliferative effects of extracts and ginsenosides on human breast cancer cells}

Using two human breast cancer cell lines MCF-7 and MDA-MB-231, the antiproliferative effect of unsteamed and steamed American ginseng root extracts were evaluated. For the MCF-7 cells, at $0.25 \mathrm{mg} / \mathrm{ml}$, unsteamed extract inhibited cell growth by $17.0 \%$. After steaming for $1 \mathrm{~h}$, the extract inhibited cell growth by $60.0 \%$ ( $P<0.01$ vs. unsteamed extract). Moreover, after cells treated with $2 \mathrm{~h}$ steamed extract, cell growth was inhibited absolutely. At $0.5 \mathrm{mg} / \mathrm{ml}$, extracts from $1 \mathrm{~h}$ and $2 \mathrm{~h}$ steamed roots inhibited cell growth over $99.6 \%$ (Figure 4A). For the MDA-MB-231 cells, at $0.25 \mathrm{mg} / \mathrm{ml}$, extracts from unsteamed and $1 \mathrm{~h}$ steamed roots did not show a antiproliferative effect, while extract from $2 \mathrm{~h}$ steamed roots showed a very strong effect, as cell growth was inhibited by $99.2 \%$ (Figure 4B). These results suggested that steaming on American ginseng roots increased antiproliferative effects on human breast cancer cells, and the effects of extract from root steamed for $2 \mathrm{~h}$ were more potent than that of root steamed for $1 \mathrm{~h}$.

Four representative ginsenosides were used to test for antiproliferative effects on breast cancer cells. Among them, two ginsenosides (Rb1 and Re) were major constituents in unsteamed American ginseng roots, while two other ginsenosides ( $\operatorname{Rg} 2$ and $\mathrm{Rg} 3$ ) were main 
constituents in steamed roots. At 30-300 $\mu \mathrm{M}$, after $72 \mathrm{~h}$ treatment, ginsenosides Rb1, Re and Rg2 did not show antiproliferative effects on MCF-7 and MDA-MB-231 cells. Ginsenoside Rg3 showed positive antiproliferative effect on both the cancer cell lines. At $100 \mu \mathrm{M}$, ginsenoside Rg3 inhibited cell growth by $49.8 \%$ on MCF-7 cells, and by $27.3 \%$ on MDA-MB231 cells (both $P<0.01$ vs. untreated control). At $300 \mu \mathrm{M}$, ginsenoside Rg3 almost inhibited cell growth on both the cell lines absolutely (Figure 4C and 4D).

A

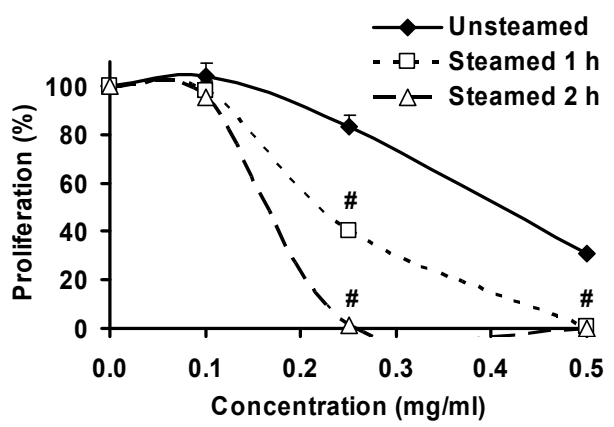

C

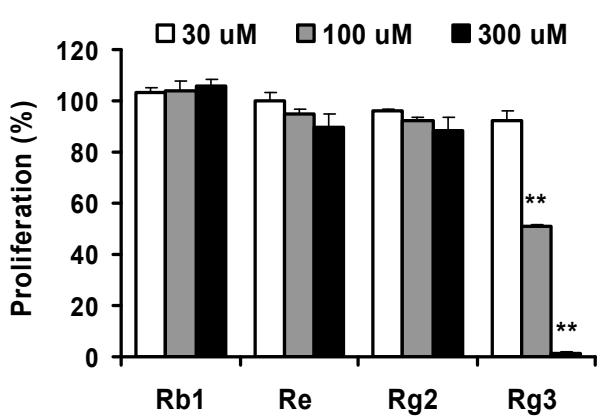

B

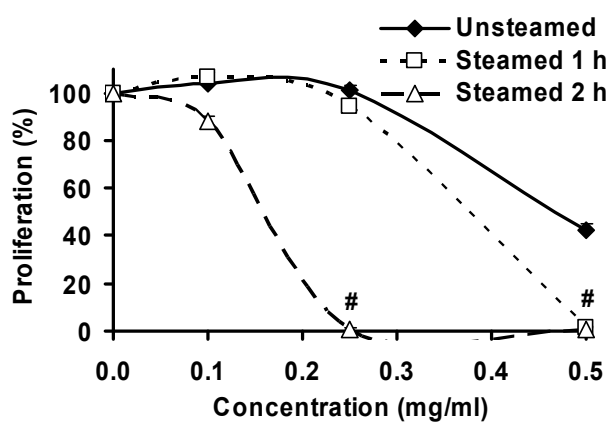

D

Fig. 4. Effects of American ginseng extracts and ginsenosides on proliferation of MCF-7 (A, C) and MDA-MB-231 (B, D) human breast cancer cells. Cells were treated with extracts (A, $B$ ) or ginsenosides $(C, D)$ for $72 \mathrm{~h}$, and then assayed by MTS method. \#, $P<0.01$ vs. unsteamed extract; **, $P<0.01$ vs. control.

\subsection{Apoptotic effect of extracts and ginsenosides on MCF-7 cells}

Apoptosis and necrosis were evaluated in MCF-7 cells using annexin V-FITC, which detects translocation of phosphatidylinositol from the inner to outer cell membrane during early apoptosis, and propidium iodide, which can enter the cell in late apoptosis or necrosis. As shown in Figure 5, compared to untreated control (early apoptosis 5.7\%, late apoptosis/necrosis $6.1 \%$ ), after treatment with $0.25 \mathrm{mg} / \mathrm{ml}$ for $48 \mathrm{~h}$, unsteamed extract increased early apoptosis to $10.3 \%$, but did not influence late apoptosis/necrosis $(5.2 \%)$. After treatment with extract from $2 \mathrm{~h}$ steamed roots, early apoptosis increased slightly 
$(7.6 \%)$, and late apoptosis/necrosis increased significantly to $37.2 \%$. Since early apoptosis is considered real apoptosis, steamed extract did not show obviously activity on early apoptosis. For the viable cells, the control was $88.1 \%$, unsteamed extract was $83.8 \%$, while 2 h steamed extract was $41.5 \%$. Steamed extract significantly decrease the viable cells.

The effects of induction of apoptosis of representative ginsenosides on MCF-7 cells were also determined. Compared to control (5.5\%), after treatment with 100-300 $\mu \mathrm{M}$ of ginsenosides $\mathrm{Rb} 1$ and $\mathrm{Rg} 3$ for $48 \mathrm{~h}$, the percentage of early apoptotic cells were not increased (less than $6.2 \%$ and $5.8 \%$, respectively). At the concentration of $300 \mu \mathrm{M}$, ginsenoside Re and Rg2 increased the cell percentage of early apoptosis to $13.0 \%$ and $9.1 \%$, respectively. Consider both the apoptosis effects of steamed extract and its major ginsenosides Rb1 and Rg3, the MCF-7 cell growth inhibition activity of steamed extract may not be caused by the induction of apoptosis.

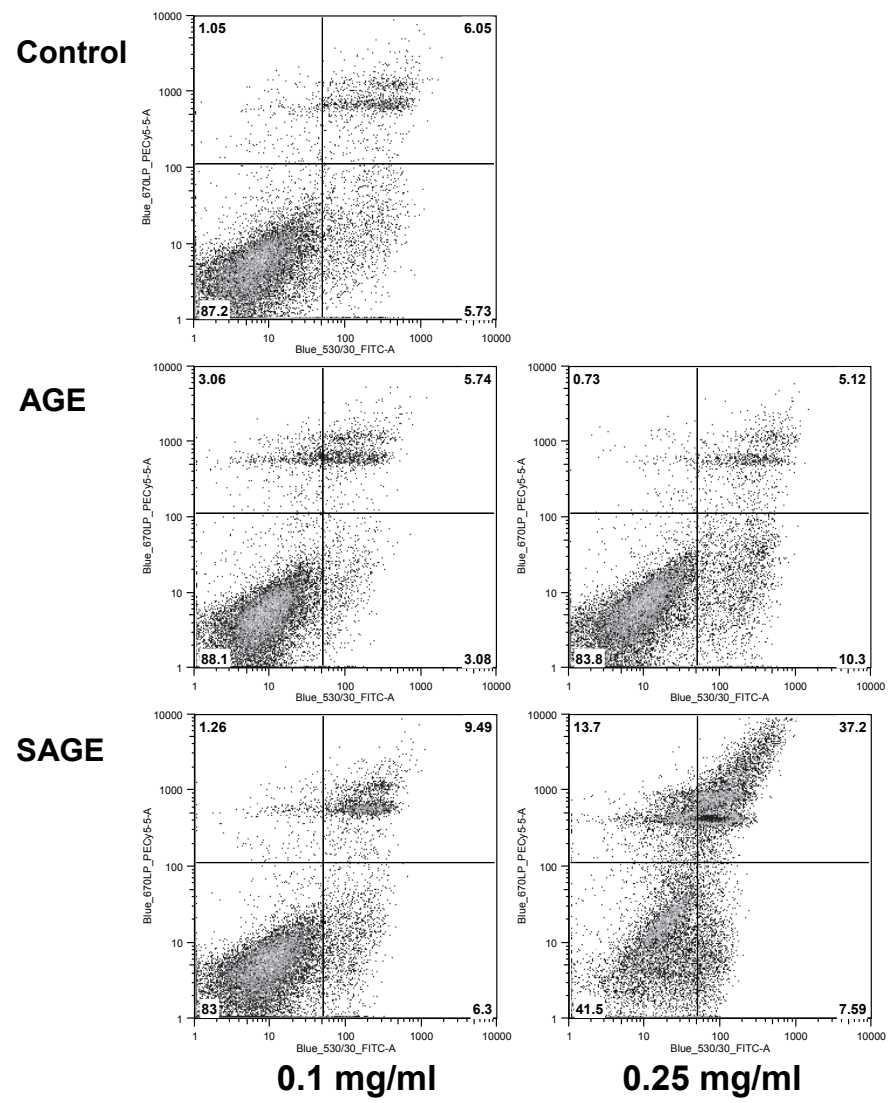

Fig. 5. Apoptosis assay using flow cytometry after annexin V-FITC/propidium iodide (PI) staining. MCF-7 cells were treated with 0.1 and $0.25 \mathrm{mg} / \mathrm{ml}$ of unsteamed and $2 \mathrm{~h}$ steamed extract for $48 \mathrm{~h}$. Viable cells are in lower left quadrant, early apoptotic cells are in lower right quadrant, late apoptotic or necrotic cells are in upper right quadrant, and non-viable cells which underwent necrosis are in upper left quadrant. 


\subsection{Effect of extracts on the expression of cyclins on MCF-7 cells}

The protein expression of cyclin A and cyclin D1 were evaluated by flow cytometry after staining with cyclin A-FITC and cyclin D1-FITC. For the percentage of cyclin A positive cells, the untreated control was $56.0 \%$. After treatment with 0.1 and $0.25 \mathrm{mg} / \mathrm{ml}$ unsteamed extract for $48 \mathrm{~h}$, the cyclin A positive cells were increased to $62.5 \%$ and $65.8 \%$, while treated with 0.1 and $0.2 \mathrm{mg} / \mathrm{ml} 2 \mathrm{~h}$ steamed extract, cyclin A positive cells were decreased to $48.4 \%$ and $14.5 \%$, respectively (Figure 6A). For cyclin D1, unsteamed extract did not influence the expression of cyclin D1, while $2 \mathrm{~h}$ steamed extract decreased the expression of cyclin D1 significantly (Figure 6B). Cyclin A and cyclin D1 are important cell cycle regulation proteins. Steamed extract decreased the expression of both cyclins, suggesting that the inhibition of cell growth of steamed extract may caused by the influences of cell cycle.
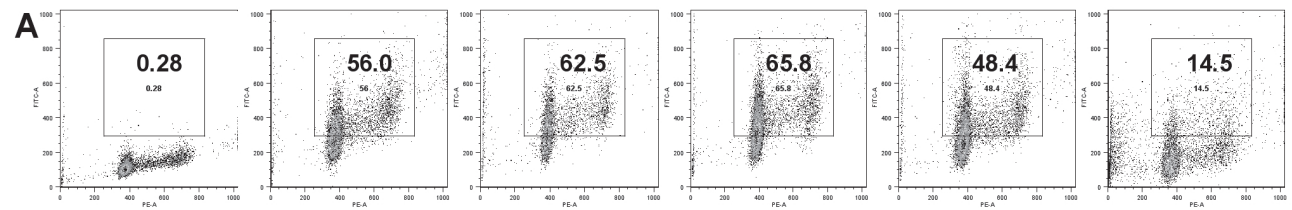

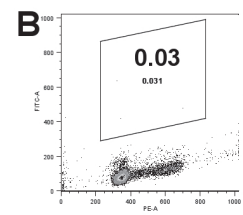

Isotype

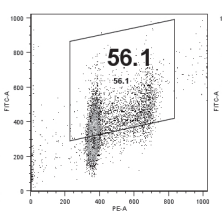

Untreated

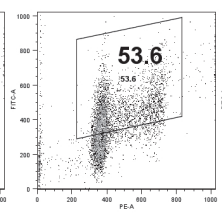

AGE $0.1 \mathrm{mg} / \mathrm{ml}$
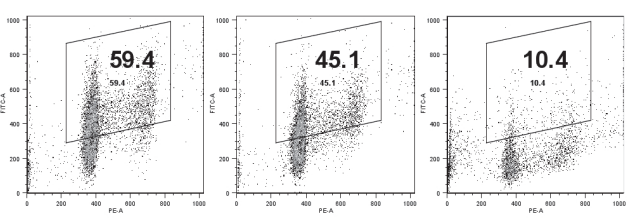

AGE $0.25 \mathrm{mg} / \mathrm{ml}$ SAGE $0.1 \mathrm{mg} / \mathrm{ml}$ SAGE $0.2 \mathrm{mg} / \mathrm{ml}$

Fig. 6. Cyclins A and D1 analysis of MCF-7 cells using flow cytometry. After treated for $48 \mathrm{~h}$, MCF-7 cells were stained with cyclin A-FITC/PI (A) and cyclin D1/PI (B). Isotype: untreated cells were stained with isotype antibody/PI. The percentage of cyclin A (A) and cyclin D1 (B) positive cells is shown in the gate.

\subsection{Effects of extracts and ginsenosides on MCF-7 cell cycle}

After treatment with unsteamed and steamed extract for $48 \mathrm{~h}$, cells were stained with propidium iodide (PI) and then assayed by flow cytometry. Unsteamed extract did not influence the cell cycle profile (Figure 7). Compared to untreated control (G1, 68.2\%), 0.2 $\mathrm{mg} / \mathrm{ml} 2 \mathrm{~h}$ steamed extract increased the percentage of cells in G1 phase to $83.6 \%$. For the single compounds, ginsenosides Rb1, Re and Rg2 almost did not influence the cell cycle. Ginsenoside Rg3, a previously recognized anticancer compound, increased the G1 fraction to $87.4 \%$ (Figure 7). Data from this study suggests that both the $2 \mathrm{~h}$ steamed extract and ginsenoside Rg3 arrested MCF-7 cells in G1 phase. 

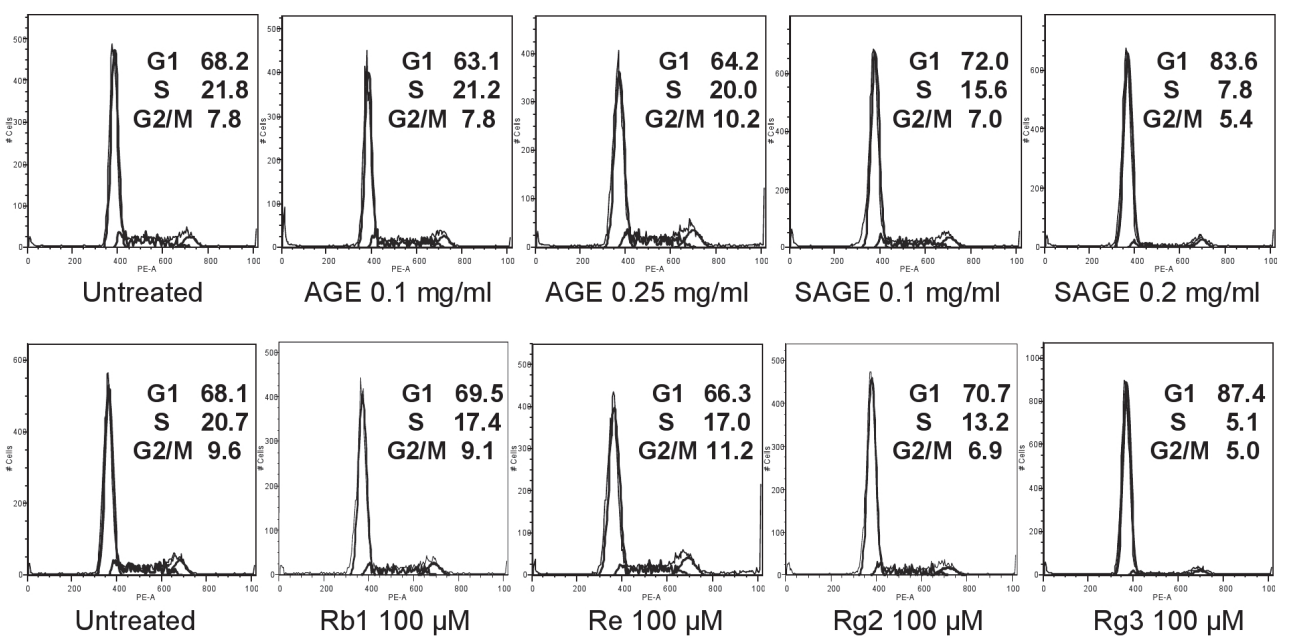

Fig. 7. Effects of extracts and ginsenosides on cell cycle. After MCF-7 cells were treated with extracts or ginsenosides for $48 \mathrm{~h}$, the cells were stained with PI and assayed using flow cytometry. The percentage of cells in G1, S and G2/M phases are indicated.

\section{Discussion}

Herbal medicines are comprised of a complicated mixture of biologically active compounds. The concentrations of these compounds may vary significantly depending on many intrinsic and extrinsic factors such as genetics, season, geographical distribution, plant growth, and production and extract processes 20 . Thus, herbal medicine identification and analysis are very important issues in the quality assurance of herbal products. Since American ginseng from Wisconsin is a reliable ginseng source 21, in this study, the American ginseng used was from Roland Ginseng, LLC (Wausau, WI). The plant material was identified according to the United States Pharmacopoeia NF 21, monograph: American ginseng (Panax quinquefolius L.). The contents of major ginsenosides in different American ginseng extracts were determined using HPLC, which means that our American ginseng extracts were standardized and the quantitative assay data are critical references for future studies.

Heat-processing on American ginseng changes the constituent profiles. We have reported the steaming temperatures and times on the changes of ginsenosides in the crude herb ${ }^{22}$. In this study, the contents of main ginsenosides in the extracts were evaluated. In unsteamed extract, the content of ginsenoside $\mathrm{Rb} 1$ was $34.2 \%$, and the summary of six ginsenosides were $63.9 \%$. The content of total ginsenoside in extract was very high, suggesting that the extraction and purification method used in this study are reasonable.

Ginsenoside Rg3, a previously recognized anticancer compound 7, was detected in the unsteamed and steamed extracts. In unsteamed extract, $\mathrm{Rg} 3$ was only a trace saponin $(0.06 \%)$. After $2 \mathrm{~h}$ steaming, the content of $\mathrm{Rg} 3$ was increased to $5.9 \%$, becoming a main constituent in the extract. Therefore, steaming on American ginseng increased $\operatorname{Rg} 3$ content significantly.

Pharmacological studies showed that heat-processing on American ginseng increases the antiproliferative effect significantly. The biological effects of extracts were based on their 
chemical constituents. We consequently evaluated the antiproliferative activities of representative ginsenosides on human breast cancer cells. Using both cancer cell lines (MCF7 and MDA-MB-231), ginsenosides $\mathrm{Rb} 1$ and Re, taken from unsteamed extract almost had no effect at the concentration range of 30-300 uM. Ginsenoside Rg3, which was taken from steamed extract, showed strong antiproliferative activity. The increase of antiproliferative effect of steam-processing is based on the increase of anticancer constituents.

Apoptosis is considered an important pathway in the inhibition of cancer cells of many anticancer agents 23,24. In this study, we assayed the induction of apoptosis by American ginseng extracts and single compounds. However, the apoptotic induction activities on MCF-7 cells were not confirmed by current data. The antiproliferative effect of red American ginseng extract on human breast cancer cells may be caused by other mechanisms.

Recent studies found that overexpression of cyclin D1 promotes tumor cell growth, and confers resistance of chemotherapy 23,24. Cyclins assay found that American ginseng extracts regulated the expression of cyclin A and cyclin D1 on MCF-7 cells. Red American ginseng extract decreased the expression of cyclin A and cyclin D1 significantly. Since cyclins are important regulation proteins in cell cycle, we assayed the influence of extract on cell cycle. Data showed that red American ginseng extract arrested cells in G1 phase, and decrease the percentage of cells in $\mathrm{S}$ and G2/M phases. We subsequently studied the influence of representative saponins on the cell cycle. Treatment with $100 \mu \mathrm{M}$ of ginsenosides $\mathrm{Rb} 1, \mathrm{Re}$ and $\operatorname{Rg} 2$ for $48 \mathrm{~h}$, did not influence the cell cycle profile. Ginsenoside $\operatorname{Rg} 3$, a main constituent in red American ginseng, arrested cells in G1 phase. This result is similar to that of red American ginseng extract.

At the concentration of $0.25 \mathrm{mg} / \mathrm{ml}, 2 \mathrm{~h}$ steamed extract inhibited cell growth absolutely. The $0.25 \mathrm{mg} / \mathrm{ml} 2 \mathrm{~h}$ steamed extract contains $18.6 \mu \mathrm{M}$ of ginsenoside Rg3. However, even 30 $\mu \mathrm{M}$ of ginsenoside Rg3 did not show significant antiproliferative activity. From the HPLC chromatogram of $2 \mathrm{~h}$ steamed extract, several peaks of unidentified compounds can be found. We expected that other more potent compounds existed in red American ginseng extract, and these compounds have similar effects to $\mathrm{Rg} 3$ on cell cycle. This should be focus of future studies.

In summary, analytical and pharmacological data obtained from our observations suggest that steamed American ginseng root significantly augments the content of ginsenoside $\operatorname{Rg} 3$ and other unidentified active compounds, which is responsible for the increase in anticancer activity. Red American ginseng, which is the heat-processed root of $P$. quinquefolius, may be a potent anti-breast cancer herbal medicine.

\section{Acknowledgements}

This work was supported in part by the NIH/NCCAM grants P01 AT004418 and K01 AT005362.

\section{References}

[1] Jemal A, Siegel R, Xu J, Ward E. Cancer statistics, 2010. CA Cancer J Clin. Sep-Oct 2010;60(5):277-300.

[2] Lee MC, Newman LA. Management of patients with locally advanced breast cancer. Surg Clin North Am. 2007;87:379-398. 
[3] Gerber B, Scholz C, Reimer T, Briese V, Janni W. Complementary and alternative therapeutic approaches in patients with early breast cancer: a systematic review. Breast Cancer Res Treat. Feb 2006;95(3):199-209.

[4] Wang CZ, Luo X, Zhang B, et al. Notoginseng enhances anti-cancer effect of 5fluorouracil on human colorectal cancer cells. Cancer Chemother Pharmacol. Jun 2007;60(1):69-79.

[5] Ang-Lee MK, Moss J, Yuan CS. Herbal medicines and perioperative care. Jama. Jul 11 2001;286(2):208-216.

[6] Attele AS, Wu JA, Yuan CS. Ginseng pharmacology: multiple constituents and multiple actions. Biochem Pharmacol. Dec 1 1999;58(11):1685-1693.

[7] Helms S. Cancer prevention and therapeutics: Panax ginseng. Altern Med Rev. Sep 2004;9(3):259-274.

[8] Yoo HH, Yokozawa T, Satoh A, Kang KS, Kim HY. Effects of ginseng on the proliferation of human lung fibroblasts. Am J Chin Med. 2006;34(1):137-146.

[9] Koo HN, Jeong HJ, Choi IY, et al. Mountain grown ginseng induces apoptosis in HL-60 cells and its mechanism have little relation with TNF-alpha production. Am J Chin Med. 2007;35(1):169-182.

[10] Yun TK, Choi SY. Preventive effect of ginseng intake against various human cancers: a case-control study on 1987 pairs. Cancer Epidemiol Biomarkers Prev. Jun 1995;4(4):401-408.

[11] Yun TK, Choi SY. Non-organ specific cancer prevention of ginseng: a prospective study in Korea. Int J Epidemiol. Jun 1998;27(3):359-364.

[12] Corbit R, Ebbs S, King ML, Murphy LL. The influence of lead and arsenite on the inhibition of human breast cancer MCF-7 cell proliferation by American ginseng root (Panax quinquefolius L.). Life Sci. Feb 16 2006;78(12):1336-1340.

[13] Aung HH, Mehendale SR, Wang CZ, Xie JT, McEntee E, Yuan CS. Cisplatin's tumoricidal effect on human breast carcinoma MCF-7 cells was not attenuated by American ginseng. Cancer Chemother Pharmacol. Feb 2007;59(3):369-374.

[14] Takaku T, Kameda K, Matsuura Y, Sekiya K, Okuda H. Studies on insulin-like substances in Korean red ginseng. Planta Med. Feb 1990;56(1):27-30.

[15] Kim WY, Kim JM, Han SB, et al. Steaming of ginseng at high temperature enhances biological activity. J Nat Prod. Dec 2000;63(12):1702-1704.

[16] Rapaka RS, Coates PM. Dietary supplements and related products: a brief summary. Life Sci. Mar 27 2006;78(18):2026-2032.

[17] Wang CZ, Wu JA, McEntee E, Yuan CS. Saponins composition in American ginseng leaf and berry assayed by high-performance liquid chromatography. J Agr Food Chem. Mar 22 2006;54(6):2261-2266.

[18] DiPaola RS, Kuczynski WI, Onodera K, et al. Evidence for a functional kit receptor in melanoma, breast, and lung carcinoma cells. Cancer Gene Ther. May-Jun 1997;4(3):176-182.

[19] Qi LW, Wang CZ, Yuan CS. American ginseng: potential structure-function relationship in cancer chemoprevention. Biochem Pharmacol. Oct 1 2010;80(7):947954.

[20] Fong HH, Pauli GF, Bolton JL, et al. Evidence-based herbal medicine: Challenges in efficacy and safety assessments. In: Leung P-C, Fong, H., Xue, C.C., ed. Current 
Review of Chinese Medicine, Annals of Traditional Chinese Medicine, Vol. 2. Singapore: World Scientific; 2006.

[21] Assinewe VA, Baum BR, Gagnon D, Arnason JT. Phytochemistry of wild populations of Panax quinquefolius L. (North American ginseng). J Agric Food Chem. Jul 30 2003;51(16):4549-4553.

[22] Wang CZ, Aung HH, Ni M, et al. Red American ginseng: ginsenoside constituents and antiproliferative activities of heat-processed Panax quinquefolius roots. Planta Med. Jun 2007;73(7):669-674.

[23] Reed JC, Pellecchia M. Apoptosis-based therapies for hematologic malignancies. Blood. Jul 15 2005;106(2):408-418.

[24] Wu WY, Guo HZ, Qu GQ, Han J, Guo DA. Mechanisms of pseudolaric Acid B-induced apoptosis in bel-7402 cell lines. Am J Chin Med. 2006;34(5):887-899. 


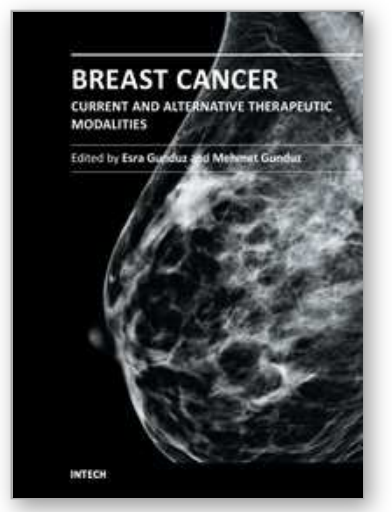

\author{
Breast Cancer - Current and Alternative Therapeutic Modalities \\ Edited by Prof. Esra Gunduz
}

ISBN 978-953-307-776-5

Hard cover, 540 pages

Publisher InTech

Published online 09, November, 2011

Published in print edition November, 2011

Cancer is the leading cause of death in most countries and its consequences result in huge economic, social and psychological burden. Breast cancer is the most frequently diagnosed cancer type and the leading cause of cancer death among females. In this book, we discussed various therapeutic modalities from signaling pathways through various anti-tumor compounds as well as herbal medicine for this deadly cancer. We hope that this book will contribute to the development of novel diagnostic as well as therapeutic approaches.

\title{
How to reference
}

In order to correctly reference this scholarly work, feel free to copy and paste the following:

Chong-Zhi Wang, Guang-Jian Du and Chun-Su Yuan (2011). Red American Ginseng and Breast Cancer, Breast Cancer - Current and Alternative Therapeutic Modalities, Prof. Esra Gunduz (Ed.), ISBN: 978-953-307776-5, InTech, Available from: http://www.intechopen.com/books/breast-cancer-current-and-alternativetherapeutic-modalities/red-american-ginseng-and-breast-cancer

\section{INTECH}

open science | open minds

\section{InTech Europe}

University Campus STeP Ri

Slavka Krautzeka 83/A

51000 Rijeka, Croatia

Phone: +385 (51) 770447

Fax: +385 (51) 686166

www.intechopen.com

\section{InTech China}

Unit 405, Office Block, Hotel Equatorial Shanghai

No.65, Yan An Road (West), Shanghai, 200040, China

中国上海市延安西路65号上海国际贵都大饭店办公楼 405 单元

Phone: +86-21-62489820

Fax: $+86-21-62489821$ 
(C) 2011 The Author(s). Licensee IntechOpen. This is an open access article distributed under the terms of the Creative Commons Attribution 3.0 License, which permits unrestricted use, distribution, and reproduction in any medium, provided the original work is properly cited. 